IZA DP No. 8385

Reassessing Labour Market Reforms: A Critique

P.N. (Raja) Junankar

Muhunthan Jayanthakumaran

August 2014

Forschungsinstitut zur Zukunft der Arbeit Institute for the Study of Labor 


\title{
Reassessing Labour Market Reforms: A Critique
}

\author{
P.N. (Raja) Junankar \\ University of New South Wales, \\ University of Western Sydney and IZA \\ Muhunthan Jayanthakumaran \\ University of New South Wales
}

\author{
Discussion Paper No. 8385 \\ August 2014
}

\author{
IZA \\ P.O. Box 7240 \\ 53072 Bonn \\ Germany \\ Phone: +49-228-3894-0 \\ Fax: +49-228-3894-180 \\ E-mail: iza@iza.org
}

\begin{abstract}
Any opinions expressed here are those of the author(s) and not those of IZA. Research published in this series may include views on policy, but the institute itself takes no institutional policy positions. The IZA research network is committed to the IZA Guiding Principles of Research Integrity.

The Institute for the Study of Labor (IZA) in Bonn is a local and virtual international research center and a place of communication between science, politics and business. IZA is an independent nonprofit organization supported by Deutsche Post Foundation. The center is associated with the University of Bonn and offers a stimulating research environment through its international network, workshops and conferences, data service, project support, research visits and doctoral program. IZA engages in (i) original and internationally competitive research in all fields of labor economics, (ii) development of policy concepts, and (iii) dissemination of research results and concepts to the interested public.
\end{abstract}

IZA Discussion Papers often represent preliminary work and are circulated to encourage discussion. Citation of such a paper should account for its provisional character. A revised version may be available directly from the author. 
IZA Discussion Paper No. 8385

August 2014

\section{ABSTRACT}

\section{Reassessing Labour Market Reforms: A Critique ${ }^{1}$}

This paper provides a critique of Faccini (2014) that allegedly shows that temporary contracts lead to lower unemployment in Europe. Using Faccini's data and his estimation methods, we show that the Fixed Effects estimation results collapse when we make slight alterations in the sample size or the independent variables used. The Arellano-Bond estimates are meaningless since the number of instruments is almost equal to the number of observations. To conclude we find that there is no evidence to support the conclusion that greater use of temporary contracts would decrease unemployment.

JEL Classification: J64, J01, J08, J21

Keywords: unemployment, temporary contracts, employment protection

Corresponding author:

P.N. (Raja) Junankar

The Australian School of Business

The University of New South Wales

UNSW Sydney NSW 2052

Australia

E-mail: raja.junankar@uws.edu.au

${ }^{1}$ Faccini, Renato (2014) Reassessing Labour Market Reforms: Temporary Contracts as a Screening Device, Economic Journal 124, 167-200. 


\section{Reassessing Labour Market Reforms: A Critique ${ }^{2}$}

\section{Introduction}

In a recent paper Faccini (2014) studies the role of temporary contracts in the labour market as a screening device. Although the theoretical literature suggests that there is an ambiguous response on unemployment, which he mentions, he then provides some econometric results (using panel data from a selected sample of European countries) that allegedly show that temporary contracts lead to lower unemployment rates. This comment argues that the econometric evidence provided (Section 2) is for a selected sample of countries and that these results are flawed. It is argued that there is selection bias in the sample, in the choice of countries, and to publish a paper in 2014, where the data sample ends in 2008, just as the global recession hit the OECD countries is likely to lead to biased results. We limit our discussion to part 2 of the paper "Reforms of Temporary Contracts, Empirical Evidence and Stylised Facts". It is, however, curious that although his estimation in Part 2 is for a selection of European countries, he calibrates his model in Part 3 with US data.

\section{A Critical Look at the Data used in Faccini's paper}

In this section we re-estimate Faccini's econometric model using the data and Stata "do" file provided on the web. Note that Faccini's estimates are for (allegedly) 18 European countries that curiously exclude Denmark and Finland but include the ex-Soviet states of the Czech Republic, Hungary, Poland, and the Slovak Republic. In fact, when the model is estimated using Stata, four countries are dropped due to incomplete data (Czech Republic, Norway, Poland, and the Slovak Republic). Although the paper was submitted originally in November 2011, his data period ends in 2008, just as the global crisis hit Europe and the OECD. Again, it is curious that he does not estimate the model for all OECD countries (including Australia, Japan, USA) for which data are available on all the relevant variables on the OECD website.

In Section 2, Reforms of Temporary Contracts, Empirical Evidence and Stylised Facts he provides a so-called Stylised Fact for Italy that a liberalisation of temporary contracts coincides with a reduction in the unemployment rate (see Figure 1). However, if we provide similar graphs for some other countries it is clear that this so-called "stylised fact" for Italy appears to be an unusual case, see Figures 2 through 4 below. For France, Germany, and Switzerland there is no association between temporary contracts and unemployment rates.

\footnotetext{
${ }^{2}$ Faccini, Renato (2014) Reassessing Labour Market Reforms: Temporary Contracts as Screening Devices", Economic Journal 124, 167-200.
} 
Figure 1: Italy: Unemployment Rate and Employment Protection Legislation

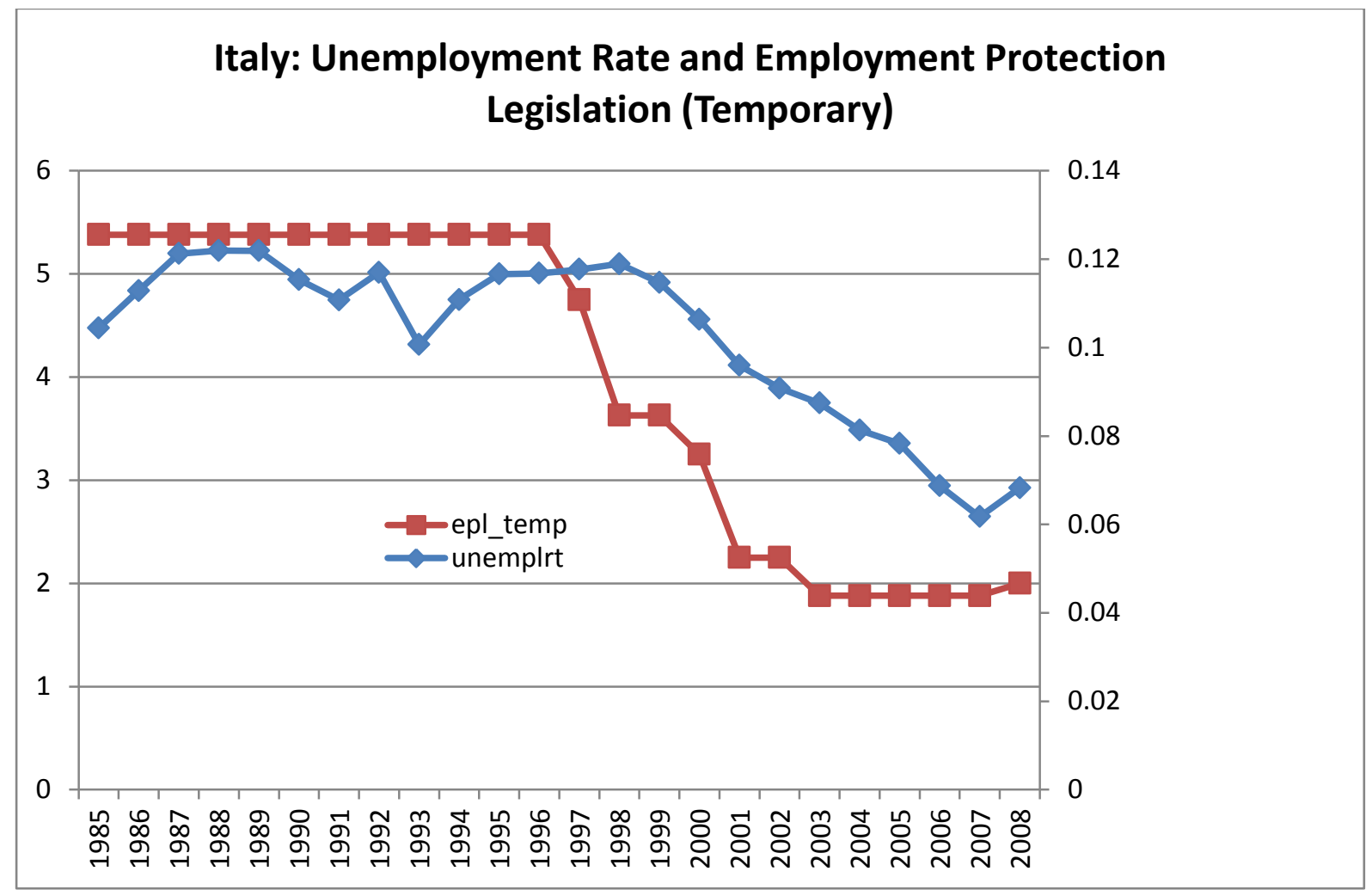

Source: Faccini (2014)

Figure 2: France: Unemployment Rate and Employment Protection Legislation

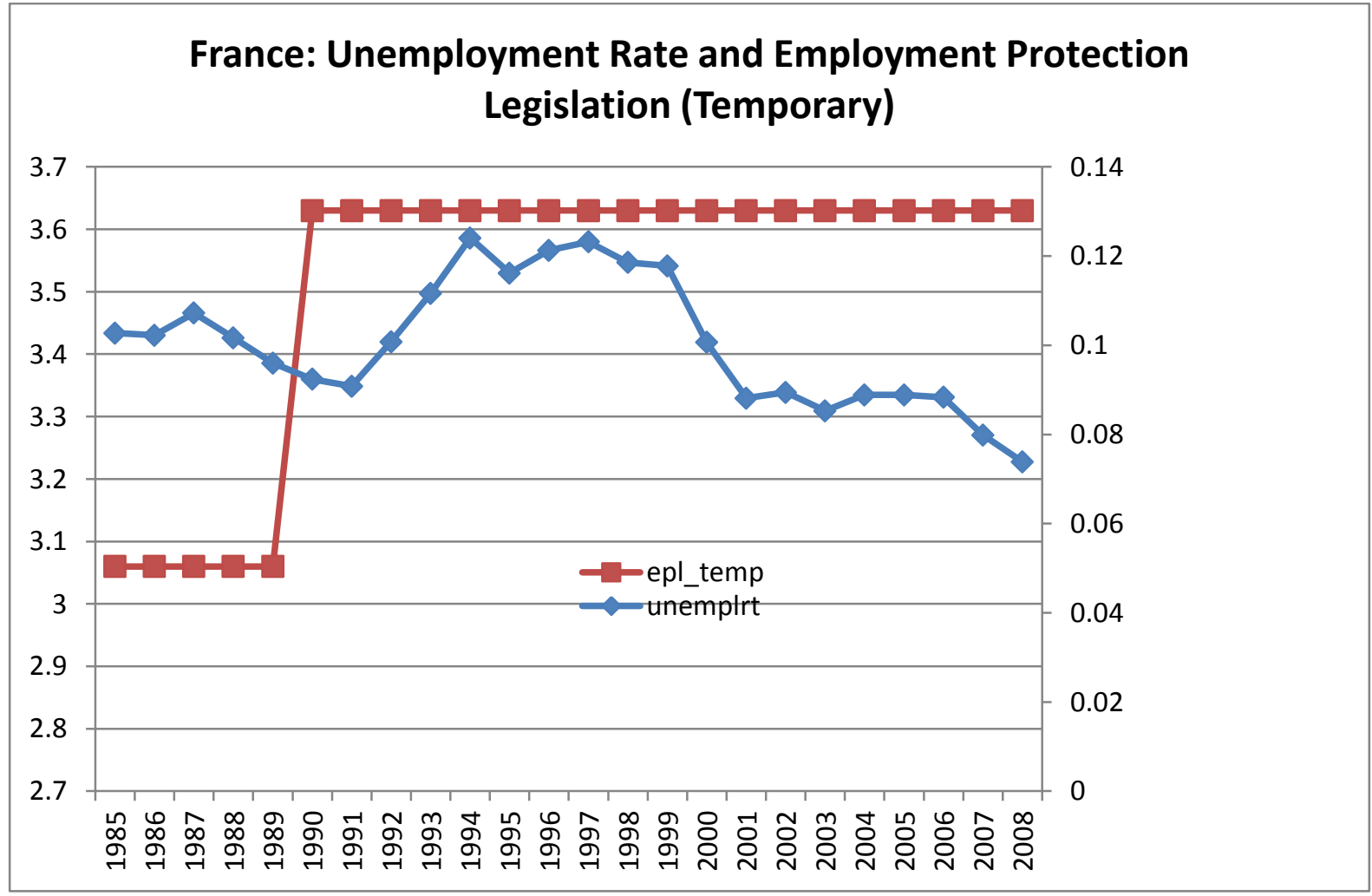

Source: Faccini (2014) 
Figure 3: Germany: Unemployment Rate and Employment Protection Legislation

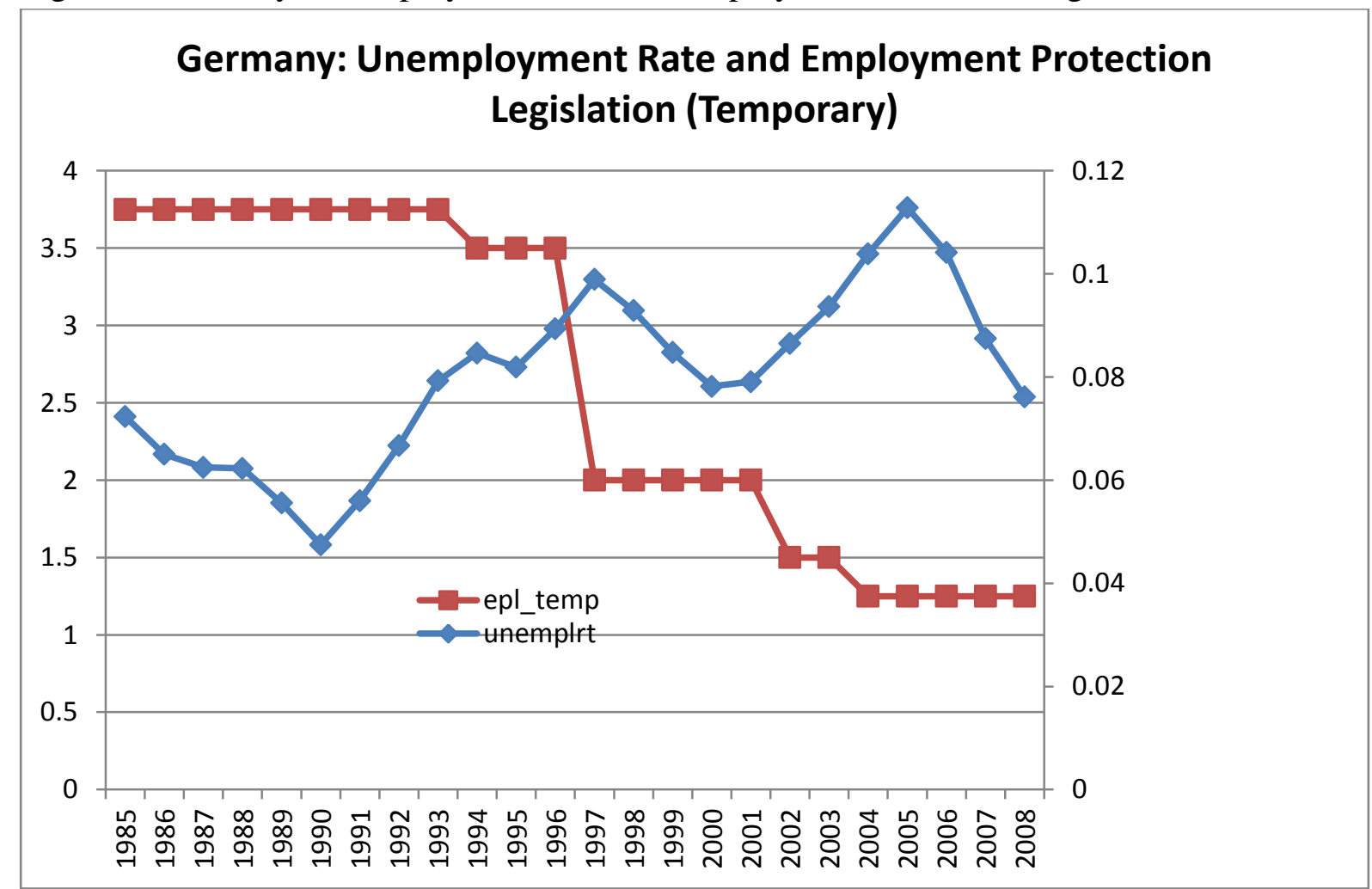

Source: Faccini (2014)

Figure 4: Switzerland: Unemployment Rate and Employment Protection Legislation

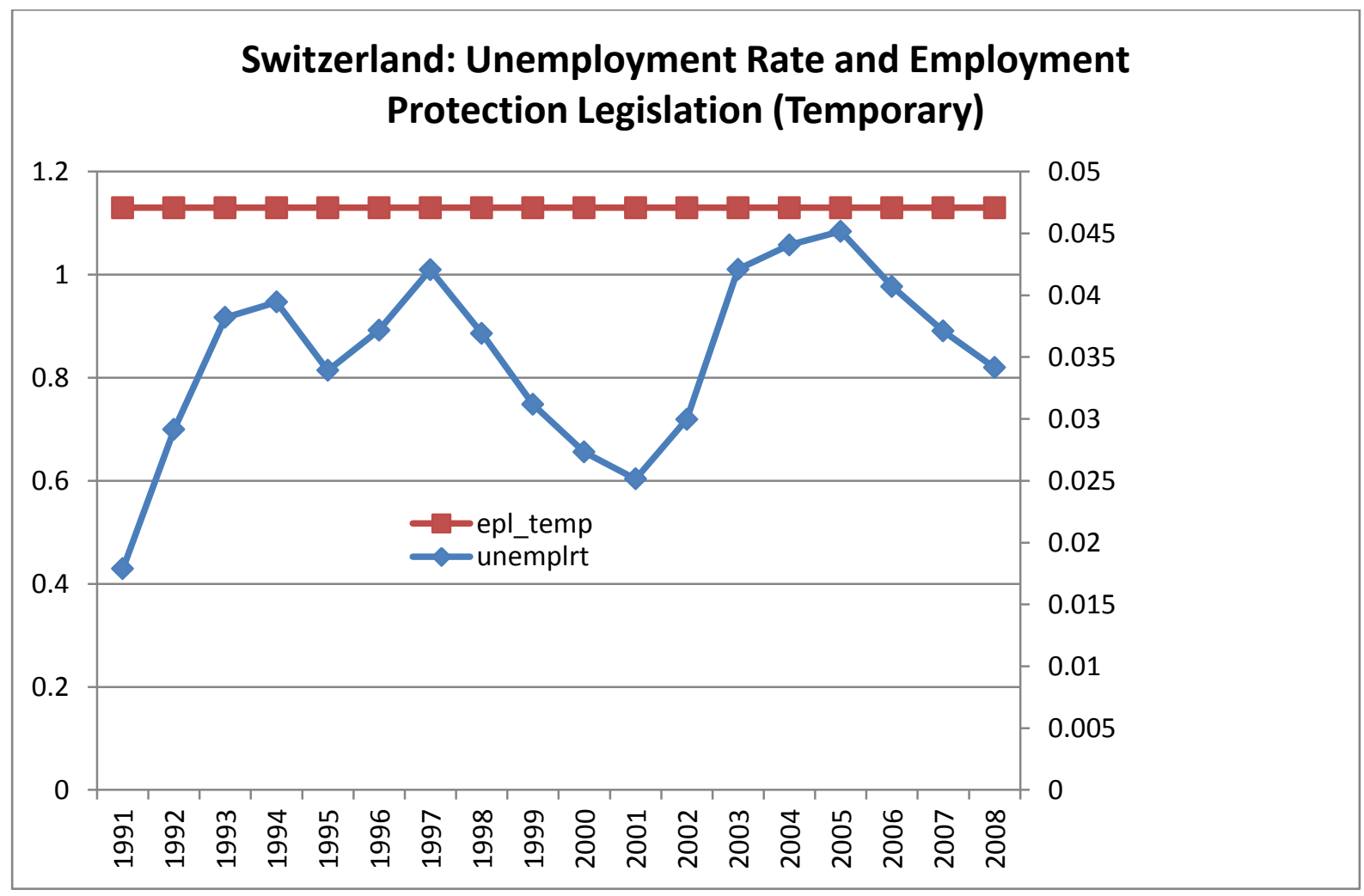

Source: Faccini (2014) 
Before we provide a critical analysis of the econometric results, let us look at the data used in Faccini's paper.

Firstly, the main point of the paper is to study the impact of changes in Employment Protection Legislation for Temporary (EPL_Temp) and Regular contracts (EPL_Reg). In fact, there were very few changes that took place in EPL, see Table 1 below. For 6 countries (one third of the countries) there was no change in the EPL_Reg, and for 2 countries there was no change in the EPL_Temp. Given the data set is a panel, there were negative changes (less employment protection) only for $3.6 \%$ of the sample for EPL_Reg and only $6.2 \%$ of the sample for EPL_Temp. For positive changes (increases in EPL_Reg) there were only $2.1 \%$ cases and $2.6 \%$ for EPL_Temp. In other words, for the sample most of the time there was no change in the EPL variables. To put it more bluntly, for only $5.7 \%$ of the sample there were changes in EPL_Reg and for only $8.8 \%$ of the sample there were changes in the EPL_Temp. In effect the results are being driven by a very small percentage of the sample.

Table 1: Changes in Employment Protection Legislation

\begin{tabular}{|c|c|c|c|}
\hline & $\begin{array}{l}\text { Emp_Reg } \\
\text { Changes }\end{array}$ & $\begin{array}{l}\text { Emp_Temp } \\
\text { Changes }\end{array}$ & $\begin{array}{l}\text { Max Poss } \\
\text { Changes }\end{array}$ \\
\hline Negative Changes & 14 & 24 & 388 \\
\hline$\%$ & 3.6 & 6.2 & \\
\hline Positive Changes & 8 & 10 & 388 \\
\hline$\%$ & 2.1 & 2.6 & \\
\hline \multirow[t]{2}{*}{ No. of Countries no Change } & 6 & 2 & 18 \\
\hline & $\begin{array}{l}\text { Hungary, Ireland, } \\
\text { Italy, Norway, } \\
\text { Poland, } \\
\text { Switzerland }\end{array}$ & $\begin{array}{l}\text { Austria \& } \\
\text { Switzerland }\end{array}$ & \\
\hline $\begin{array}{c}\text { Countries with Negative } \\
\text { Changes }\end{array}$ & 9 & 8 & 18 \\
\hline$\%$ & 50 & 44.4 & \\
\hline $\begin{array}{c}\text { Countries with Positive } \\
\text { Changes }\end{array}$ & 6 & 8 & 18 \\
\hline$\%$ & 33.3 & 44.4 & \\
\hline $\begin{array}{c}\text { Countries with Positive \& } \\
\text { Negative Changes }\end{array}$ & 3 & 4 & 18 \\
\hline$\%$ & 16.7 & 22.2 & \\
\hline
\end{tabular}

Source: Faccini data

\section{Tests of Robustness}

In this section, we subject the data used by Faccini in his econometric estimation to tests of robustness and to a critique of the estimates provided in Tables 1 and 2 of his paper. We first re-estimated the Faccini model using his data set and his Stata "do" file. First we 
look at the results in Table 1 using fixed effects, and subsequently we look at Table 2 results using one-step DGMM methods.

In Table 1 he provides estimates of a fixed effects model using instrumental variables (including Country dummies in Column 1 and Country and Time dummies in Column $2)^{3}$. The model is based on Nickell et al. (2005) that includes as independent variables Labour Demand Shocks (see his footnote 6), TFP shocks, EPL temporary contracts, EPL Regular contracts, Union density, Benefit Replacement Ratio, Benefit duration, Centralisation and Coordination, and a lagged dependent variable ${ }^{4}$. The only variables that are significant in Faccini's Table 1 are the lagged dependent variable (almost unity and very significant), EPL_Temp, EPL_Reg, and Labour Demand Shocks (the latter variable is very significant).

Our re-estimation of Table 1 from the paper is shown in Table below. The results are similar to Faccini and this gave us some confidence that we had made no errors.

\footnotetext{
${ }^{3}$ Of course, a fixed effects estimate automatically introduces country dummies. The model is estimated using Stata's ivreg2 command.

${ }^{4}$ Note all institutional variables are standardised by their standard deviations, following Nickell et al. (2005).
} 
Table 2: Unemployment Regressions Fixed Effects estimation: Replication

\begin{tabular}{|c|c|c|}
\hline \multirow[t]{2}{*}{ Independent Variables } & \multicolumn{2}{|c|}{ Dependent variable: $\mathrm{u}_{\mathrm{it}}$} \\
\hline & 1 & 2 \\
\hline \multirow[t]{2}{*}{$\mathrm{u}_{\mathrm{it}-1}$} & $0.871 * * *$ & $0.869 * * *$ \\
\hline & $(0.0363)$ & $(0.0313)$ \\
\hline \multirow[t]{2}{*}{ EPL temporary contracts ${ }_{i t}$} & $0.421 * * *$ & $0.264 *$ \\
\hline & $(0.128)$ & $(0.142)$ \\
\hline \multirow[t]{2}{*}{ EPL regular contracts ${ }_{\text {it }}$} & $0.907 *$ & $0.783 * *$ \\
\hline & $(0.512)$ & $(0.372)$ \\
\hline \multirow[t]{2}{*}{ Benefit replacement ratio $_{\text {it }}$} & 0.0792 & 0.194 \\
\hline & $(0.163)$ & $(0.160)$ \\
\hline \multirow[t]{2}{*}{ Benefit duration $_{\text {it }}$} & -0.186 & $-0.249 *$ \\
\hline & $(0.115)$ & $(0.137)$ \\
\hline \multirow[t]{2}{*}{ Centralisation $_{\mathrm{it}}$} & $0.369 * *$ & $0.249^{*}$ \\
\hline & $(0.163)$ & $(0.138)$ \\
\hline \multirow[t]{2}{*}{ Co-ordination $_{\text {it }}$} & -0.117 & -0.197 \\
\hline & $(0.225)$ & $(0.184)$ \\
\hline \multirow[t]{2}{*}{ Union density $_{\text {it }}$} & 0.383 & -0.0742 \\
\hline & $(0.293)$ & $(0.260)$ \\
\hline \multirow[t]{2}{*}{ Labour demand shocks ${ }_{\text {it }}$} & $-0.363 * * *$ & $-0.283 * * *$ \\
\hline & $(0.0698)$ & $(0.0556)$ \\
\hline \multirow[t]{2}{*}{ TFP shocks ${ }_{\text {it }}$} & -0.00645 & -0.0208 \\
\hline & $(0.0187)$ & $(0.0150)$ \\
\hline Time dummies & No & Yes \\
\hline Country dummies & Yes & Yes \\
\hline Observations & 241 & 241 \\
\hline
\end{tabular}

Note that in Table 1 of the paper, Faccini reports the Hausman test (columns 1 and 2) but this is not reported in our re-estimation in Table 2. We assume that Faccini is comparing a fixed effects model with a random effects model and finds the fixed effects model to be superior.

Note that once we have a dynamic equation (with a lagged dependent variable included), fixed effects estimates have certain shortcomings. This is because of asymptotic endogeneity bias caused by the lagged dependent variable (Nickell, 1981). This impact reduces as number of time points increases or the coefficient of the lagged term reduces. Faccini includes 14 countries (note that in the estimation four countries are dropped due to a lack of observations) and 24 years and a coefficient of close to 0.9 for the lagged coefficient. This means that the results for Table 1 in his paper are likely biased. 
We then re-estimated the model excluding the ex-Soviet country Hungary (as other ex-Soviet countries were already excluded due to lack of data) and found that the EPL_Temp was no longer significant when country and time dummies were included and marginally significant at ten percent when only country dummies were included, see Table 3 below for Fixed Effects estimation respectively. It is also worth noting that except for the lagged dependent variable and labour demand shocks that are significant at the one percent level and EPL_regular contracts significant at five percent level, all other variables are not statistically significant (column 2 of Table 3).

Table 3: Unemployment Regressions Fixed Effects estimation: Excluding Hungary from sample

\begin{tabular}{|c|c|c|}
\hline \multirow[t]{2}{*}{ Independent Variables } & \multicolumn{2}{|c|}{ Dependent variable: $\mathrm{u}_{\mathrm{it}}$} \\
\hline & 1 & 2 \\
\hline \multirow[t]{2}{*}{$\mathrm{u}_{\mathrm{it}-1}$} & $0.861 * * *$ & $0.869 * * *$ \\
\hline & $(0.0375)$ & $(0.0317)$ \\
\hline \multirow[t]{2}{*}{ EPL temporary contracts $_{\text {it }}$} & $0.274^{*}$ & 0.242 \\
\hline & $(0.143)$ & $(0.149)$ \\
\hline \multirow[t]{2}{*}{ EPL regular contracts ${ }_{i t}$} & $0.923^{*}$ & $0.833 * *$ \\
\hline & $(0.500)$ & $(0.363)$ \\
\hline \multirow{2}{*}{ Benefit replacement ratio $_{\text {it }}$} & 0.0448 & 0.191 \\
\hline & $(0.167)$ & $(0.161)$ \\
\hline \multirow[t]{2}{*}{ Benefit duration $_{\text {it }}$} & -0.151 & $-0.240 *$ \\
\hline & $(0.115)$ & $(0.138)$ \\
\hline \multirow[t]{2}{*}{ Centralisation $_{\text {it }}$} & $0.310 * *$ & 0.219 \\
\hline & $(0.158)$ & $(0.137)$ \\
\hline \multirow[t]{2}{*}{ Co-ordination $_{\text {it }}$} & -0.102 & -0.175 \\
\hline & $(0.216)$ & $(0.181)$ \\
\hline \multirow[t]{2}{*}{ Union density ${ }_{\mathrm{it}}$} & $1.118^{* * *}$ & 0.455 \\
\hline & $(0.424)$ & $(0.502)$ \\
\hline \multirow[t]{2}{*}{ Labour demand shocks ${ }_{\text {it }}$} & $0.375^{* * *}$ & $-0.292 * * *$ \\
\hline & $(0.0723)$ & $(0.0591)$ \\
\hline \multirow[t]{2}{*}{ TFP shocks $_{\text {it }}$} & -0.0128 & -0.0248 \\
\hline & $(0.0200)$ & $(0.0174)$ \\
\hline Time dummies & No & Yes \\
\hline Country dummies & Yes & Yes \\
\hline Observations & 227 & 227 \\
\hline \multicolumn{3}{|c|}{$\begin{array}{l}\text { Notes: } *, * * \text { and } * * * \text { denote statistical significance at the } 10 \%, 5 \% \text { and } 1 \% \text { levels respectively } \\
\text { Standard errors are reported in parentheses. The models use generalised least squares, correcting } \\
\text { for heteroscedascity and serial correlation of unknown form and are the same as columns } 1 \text { and } 2 \\
\text { of table } 1 \text { from Faccini's results. The only change made to the code was dropping ex-Sovie } \\
\text { countries. }\end{array}$} \\
\hline
\end{tabular}

Given the impact of removing Hungary from the sample it would be worthwhile to see if dropping other countries (with replacement) would have a similar effect. We then re- 
estimated this fixed effects model (excluding Hungary) by the process of eliminating one country at a time (and replacing it). This shows that the results of Table 1 are also very sensitive to this exclusion. In particular, when we dropped Spain from the sample, we found that EPL_regular contracts changes sign from being positive in Table 1 of Faccini to becoming negative although not significant, see Table 4 below. Here we see that the EPL_temporary contracts variable is no longer significant, in other words, employment strong protection of temporary contracts does not increase unemployment! Centralisation becomes significant suggesting that a more centralised an economy the higher the unemployment rate.

Table 4: Unemployment Regressions Fixed Effects Estimation: Excluding Spain (and Hungary) from sample

\begin{tabular}{|c|c|c|}
\hline \multirow[t]{2}{*}{ Independent Variables } & \multicolumn{2}{|c|}{ Dependent variable: $\mathrm{u}_{\mathrm{it}}$} \\
\hline & 1 & 2 \\
\hline \multirow[t]{2}{*}{$\mathrm{u}_{\mathrm{it}-1}$} & $0.826 * * *$ & $0.852 * * *$ \\
\hline & $(0.0287)$ & $(0.0273)$ \\
\hline \multirow[t]{2}{*}{ EPL temporary contracts ${ }_{i t}$} & 0.179 & 0.201 \\
\hline & $(0.142)$ & $(0.136)$ \\
\hline \multirow[t]{2}{*}{ EPL regular contracts ${ }_{i t}$} & $-0.566^{*}$ & -0.254 \\
\hline & $(0.340)$ & $(0.277)$ \\
\hline \multirow[t]{2}{*}{ Benefit replacement ratio $_{\text {it }}$} & 0.0244 & 0.151 \\
\hline & $(0.172)$ & $(0.156)$ \\
\hline \multirow[t]{2}{*}{ Benefit duration $_{\text {it }}$} & -0.105 & -0.180 \\
\hline & $(0.119)$ & $(0.129)$ \\
\hline \multirow[t]{2}{*}{ Centralisation $_{\text {it }}$} & $0.368 * *$ & $0.318^{* *}$ \\
\hline & $(0.155)$ & $(0.130)$ \\
\hline \multirow[t]{2}{*}{ Co-ordination $_{\mathrm{it}}$} & -0.217 & -0.227 \\
\hline & $(0.200)$ & $(0.172)$ \\
\hline \multirow[t]{2}{*}{ Union density ${ }_{\mathrm{it}}$} & $1.199 * * *$ & 0.546 \\
\hline & $(0.407)$ & $(0.493)$ \\
\hline \multirow[t]{2}{*}{ Labour demand shocks ${ }_{\mathrm{it}}$} & $-0.356^{* * *}$ & $-0.271 * * *$ \\
\hline & $(0.0712)$ & $(0.0557)$ \\
\hline \multirow[t]{2}{*}{ TFP shocks ${ }_{\text {it }}$} & -0.00693 & -0.0119 \\
\hline & $(0.0188)$ & $(0.0174)$ \\
\hline Time dummies & No & Yes \\
\hline Country dummies & Yes & Yes \\
\hline Observations & 208 & 208 \\
\hline \multicolumn{3}{|c|}{$\begin{array}{l}\text { Notes: } *, * * \text { and } * * * \text { denote statistical significance at the } 10 \%, 5 \% \text { and } 1 \% \text { levels respectively. } \\
\text { Standard errors are reported in parentheses. The models use generalised least squares, correcting } \\
\text { for heteroscedascity and serial correlation of unknown form and are the same as columns } 1 \text { and } 2 \\
\text { of table } 1 \text { from Faccini's results. The only change made to the code was dropping Spain from the } \\
\text { sample. }\end{array}$} \\
\hline
\end{tabular}


Finally in re-estimating the fixed effects model we dropped the variable "Labour Demand Shocks" which was defined as "the residuals from country specific equations, each being a regression of employment on lags of employment, real wages and output" (footnote 2, p. 174). It is surprising that anyone would include this variable as it would by definition affect unemployment (assuming that the changes in participation rates are small). Of course, if employment falls we would expect to find unemployment increasing!

These results (excluding labour demand shocks) are very interesting, see Table 5 below. The only variable in the fixed effects estimation that is statistically significant is the lagged dependent variable. In other words, the model implodes: none of the other variables is significant at the $5 \%$ level. It is also worth noting that the sample size without this variable increases from 241 to 293 . Obviously, there were many missing values for this variable.

Table 5: Unemployment Regressions Fixed Effects Estimation: Excluding labour demand shocks

\begin{tabular}{|c|c|c|}
\hline \multirow[t]{2}{*}{ Independent Variables } & \multicolumn{2}{|c|}{ Dependent variable: $u_{i t}$} \\
\hline & 1 & 2 \\
\hline \multirow[t]{2}{*}{$\mathrm{u}_{\mathrm{it}-1}$} & $0.886^{* * *}$ & $0.901 * * *$ \\
\hline & $(0.0245)$ & $(0.0260)$ \\
\hline \multirow[t]{2}{*}{ EPL temporary contracts ${ }_{\text {it }}$} & 0.199 & 0.176 \\
\hline & $(0.139)$ & $(0.142)$ \\
\hline \multirow[t]{2}{*}{ EPL regular contracts ${ }_{\text {it }}$} & 0.267 & 0.329 \\
\hline & $(0.434)$ & $(0.308)$ \\
\hline \multirow[t]{2}{*}{ Benefit replacement ratio $_{\text {it }}$} & -0.00852 & 0.0971 \\
\hline & $(0.172)$ & $(0.157)$ \\
\hline \multirow[t]{2}{*}{ Benefit duration $_{\text {it }}$} & -0.0263 & $-0.234^{*}$ \\
\hline & $(0.113)$ & $(0.135)$ \\
\hline \multirow[t]{2}{*}{ Centralisation $_{\text {it }}$} & 0.201 & 0.166 \\
\hline & $(0.161)$ & $(0.119)$ \\
\hline \multirow[t]{2}{*}{ Co-ordination $_{\text {it }}$} & -0.25 & -0.312 \\
\hline & $(0.261)$ & $(0.192)$ \\
\hline \multirow[t]{2}{*}{ Union density ${ }_{i t}$} & 0.223 & -0.266 \\
\hline & $(0.250)$ & $(0.254)$ \\
\hline \multirow[t]{2}{*}{ TFP shocks ${ }_{\text {it }}$} & 0.00486 & -0.0249 \\
\hline & $(0.0187)$ & $(0.0159)$ \\
\hline Time dummies & No & Yes \\
\hline Country dummies & Yes & Yes \\
\hline Observations & 293 & 293 \\
\hline \multicolumn{3}{|c|}{$\begin{array}{l}\text { Notes: } *, * * \text { and } * * * \text { denote statistical significance at the } 10 \%, 5 \% \text { and } 1 \% \text { levels respectively } \\
\text { Standard errors are reported in parentheses. The models use generalised least squares, correcting } \\
\text { for heteroscedascity and serial correlation of unknown form and are the same as columns } 1 \text { and } 2 \\
\text { of table } 1 \text { from Faccini's results. The only change made to the code was excluding labour demand } \\
\text { shocks variable. }\end{array}$} \\
\hline
\end{tabular}


In the next stage of our tests of robustness we re-estimated Faccini's Table 2 using the Arellano_Bond one-step DGMM estimation method and these results are presented in Table 6. Unlike Faccini, we have used robust standard errors (as they are more appropriate) and also included a Sargan and a Hansen test for the validity of instruments. Note that we have used his Stata code for the instrument set. Although he provides results with two alternative instrument sets, we found the results were very similar with either set. As such all the results provided below are using his instrument set 1 . This set comprises of all lags of dependent variables and the second lag of all other independent variables.

If we compare our results with Faccini's Table 2 we note that EPL_temporary contracts is not statistically significant if we include time dummies, while EPL_regular contracts is significant. Also note that the variable benefit duration is negative and significant. Table 6 below we find that in all the equations in Table 2 the Hansen test for instrument validity results in a nonsensical value of one. The Sargan test tends to reject the null with values of 0 for all models implying that overidentifying restrictions of the instruments are not valid. Faccini is obviously aware of the problems as he states "given that the cross-section is small, a fixed effects estimation is preferable to GMM as the estimates of the coefficients might be quite sensitive to the instruments" (p. 174) but nonetheless provides GMM results without quoting the Sargan or Hansen instrument validity tests. These results are clearly meaningless and should therefore be ignored. 
Table 6: Unemployment Regressions Arellano-Bond Estimation: Replication

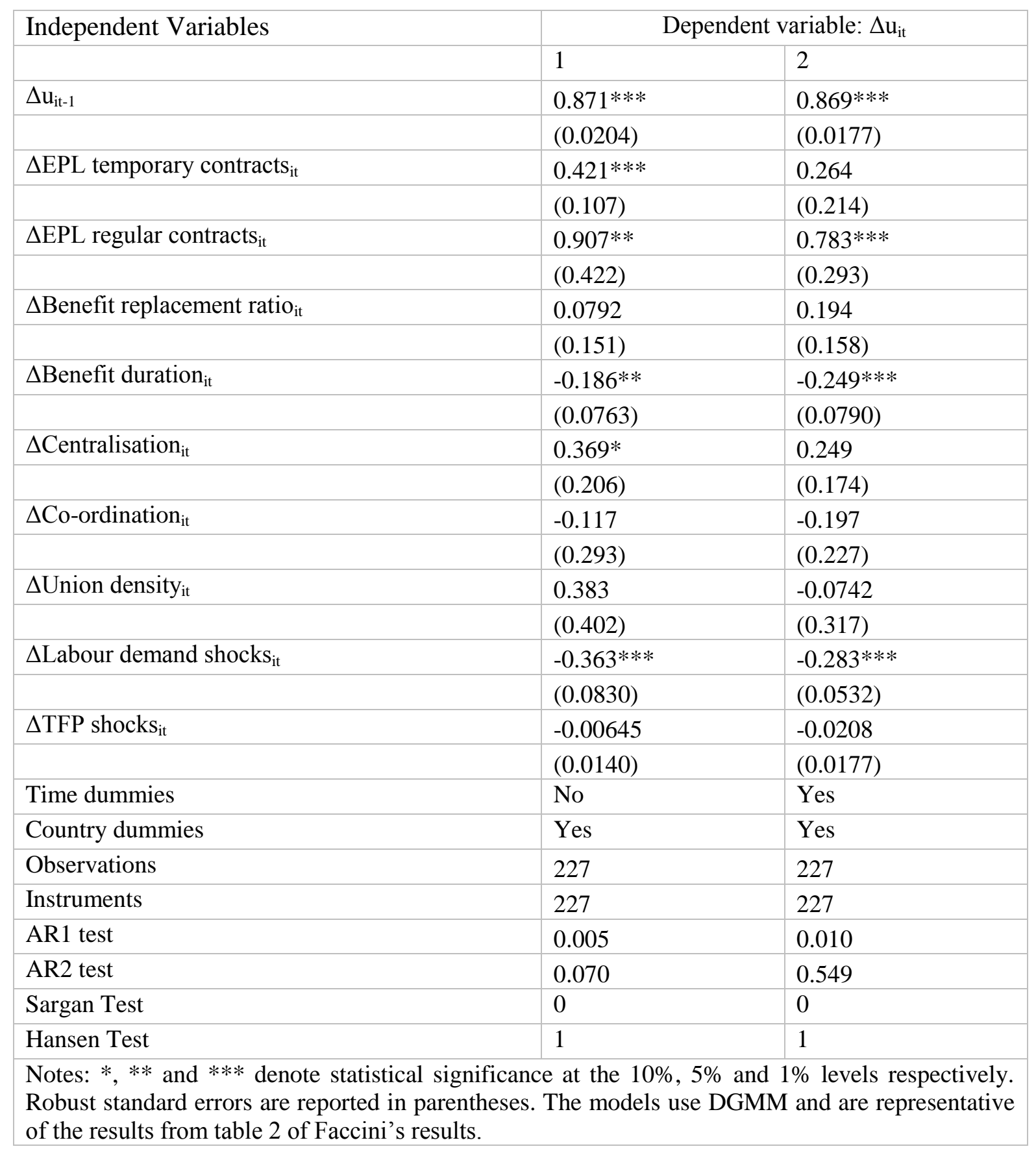

In our replications, a Sargan test tends to reject the null with values of 0 for all models implying that overidentifying restrictions of the instruments are not valid. Conversely Hansen test provides overwhelming evidence that instruments are valid with a value of 1 by failing to reject the null. This value of 1 is very suspicious and this is related to the potentially excessive number of instruments used in the model. Note, that Faccini does not quote the number of observations and instruments used in his paper. As Roodman (2009) shows that this method, xtabond 2 is very sensitive to the number of instruments and that any research should provide this information. In all these estimations the number of instruments is very large and in all cases equals the number of observations, except in Table 9 below when the 
number of instruments is slightly less than the number of observations. Given the large number of instruments it is not surprising that the instrument validity tests give nonsensical results.

In Table 7 we present results using the Arellano-Bond method of estimation (excluding Hungary) and the results are similar to Table 6. Again there are problems with the instrument validity test, the number of instruments is equal to the number of observations!

Excluding Spain from the sample gives results (Table 8) which are very similar to the earlier ones in Tables 6 and 7. One difference is that EPL_regular contracts is no longer significant but has changed sign and become negative. 
Table 7: Unemployment Regressions Arellano-Bond Estimation: Excluding Hungary from the sample

\begin{tabular}{|c|c|c|}
\hline \multirow[t]{2}{*}{ Independent Variables } & \multicolumn{2}{|c|}{ Dependent variable: $\Delta \mathrm{u}_{\mathrm{it}}$} \\
\hline & 1 & 2 \\
\hline \multirow[t]{2}{*}{$\Delta \mathrm{u}_{\mathrm{it}-1}$} & $0.861 * * *$ & $0.869 * * *$ \\
\hline & $(0.0238)$ & $(0.0206)$ \\
\hline \multirow[t]{2}{*}{$\Delta \mathrm{EPL}$ temporary contracts $\mathrm{sit}_{\mathrm{i}}$} & $0.274 * *$ & 0.242 \\
\hline & $(0.117)$ & $(0.233)$ \\
\hline \multirow[t]{2}{*}{$\Delta \mathrm{EPL}$ regular contracts ${ }_{\mathrm{it}}$} & $0.923 * *$ & $0.833 * * *$ \\
\hline & $(0.438)$ & $(0.315)$ \\
\hline \multirow[t]{2}{*}{$\Delta$ Benefit replacement ratio $_{\text {it }}$} & 0.0448 & 0.191 \\
\hline & $(0.172)$ & $(0.170)$ \\
\hline \multirow[t]{2}{*}{$\Delta$ Benefit duration $_{\text {it }}$} & $-0.151^{* *}$ & $-0.240 * * *$ \\
\hline & $(0.0699)$ & $(0.0837)$ \\
\hline \multirow[t]{2}{*}{$\Delta$ Centralisation $_{\text {it }}$} & 0.310 & 0.219 \\
\hline & $(0.200)$ & $(0.177)$ \\
\hline \multirow[t]{2}{*}{$\Delta$ Co-ordination ${ }_{\text {it }}$} & -0.102 & -0.175 \\
\hline & $(0.280)$ & $(0.224)$ \\
\hline \multirow[t]{2}{*}{$\Delta$ Union density $_{\mathrm{it}}$} & $1.118 * * *$ & 0.455 \\
\hline & $(0.386)$ & $(0.545)$ \\
\hline \multirow[t]{2}{*}{$\Delta$ Labour demand shocks $_{\text {it }}$} & $-0.375 * * *$ & $-0.292 * * *$ \\
\hline & $(0.0861)$ & $(0.0588)$ \\
\hline \multirow[t]{2}{*}{$\Delta \mathrm{TFP}$ shocks $_{\mathrm{it}}$} & -0.0128 & -0.0248 \\
\hline & $(0.0151)$ & $(0.0222)$ \\
\hline Time dummies & No & Yes \\
\hline Country dummies & Yes & Yes \\
\hline Observations & 214 & 214 \\
\hline Instruments & 214 & 214 \\
\hline AR1 test & 0.008 & 0.011 \\
\hline AR2 test & 0.120 & 0.648 \\
\hline Sargan Test & 0 & 0 \\
\hline Hansen Test & 1 & 1 \\
\hline
\end{tabular}

Table 8: Unemployment Regressions Arellano-Bond Estimation: Excluding Spain from the sample

Independent Variables

Dependent variable: $\Delta \mathrm{u}_{\mathrm{it}}$

\begin{tabular}{|l|l|l|}
\hline & 1 & 2 \\
\hline$\Delta \mathrm{u}_{\mathrm{it}-1}$ & $0.843 * * *$ & $0.859 * * *$ \\
\hline & $(0.0144)$ & $(0.0228)$ \\
\hline
\end{tabular}




\begin{tabular}{|c|c|c|}
\hline \multirow[t]{2}{*}{$\Delta \mathrm{EPL}$ temporary contracts it } & $0.335 * * *$ & 0.239 \\
\hline & $(0.109)$ & $(0.185)$ \\
\hline \multirow[t]{2}{*}{$\Delta \mathrm{EPL}$ regular contracts ${ }_{\mathrm{it}}$} & -0.562 & -0.236 \\
\hline & $(0.367)$ & $(0.320)$ \\
\hline \multirow{2}{*}{$\Delta{\text { Benefit replacement } \text { ratio }_{\text {it }}}$} & 0.0686 & 0.170 \\
\hline & $(0.141)$ & $(0.141)$ \\
\hline \multirow[t]{2}{*}{$\Delta$ Benefit duration $_{\mathrm{it}}$} & $-0.144 * *$ & $-0.194 * * *$ \\
\hline & $(0.0707)$ & $(0.0608)$ \\
\hline \multirow[t]{2}{*}{$\Delta$ Centralisation $_{\text {it }}$} & $0.430 * *$ & $0.350 * *$ \\
\hline & $(0.213)$ & $(0.174)$ \\
\hline \multirow[t]{2}{*}{$\Delta$ Co-ordination $_{\text {it }}$} & -0.233 & -0.252 \\
\hline & $(0.283)$ & $(0.239)$ \\
\hline \multirow[t]{2}{*}{$\Delta$ Union density $_{\mathrm{it}}$} & 0.437 & -0.0187 \\
\hline & $(0.402)$ & $(0.367)$ \\
\hline \multirow[t]{2}{*}{$\Delta$ Labour demand shocks $_{\text {it }}$} & $-0.344 * * *$ & $-0.266^{* * *}$ \\
\hline & $(0.0916)$ & $(0.0660)$ \\
\hline \multirow[t]{2}{*}{$\Delta$ TFP shocks ${ }_{i t}$} & -0.00191 & -0.0112 \\
\hline & $(0.0133)$ & $(0.0174)$ \\
\hline Time dummies & No & Yes \\
\hline Country dummies & Yes & Yes \\
\hline Observations & 209 & 209 \\
\hline Instruments & 209 & 209 \\
\hline AR1 test & 0.009 & 0.022 \\
\hline AR2 test & 0.023 & 0.026 \\
\hline Sargan Test & 0 & 0 \\
\hline Hansen Test & 1 & 1 \\
\hline \multicolumn{3}{|c|}{$\begin{array}{l}\text { Notes: } *, * * \text { and } * * * \text { denote statistical significance at the } 10 \%, 5 \% \text { and } 1 \% \text { levels respectively. } \\
\text { Robust standard errors are reported in parentheses. The models use DGMM and are representative } \\
\text { of the results from Table } 2 \text { of Faccini's results. Both models use instruments comprising of all lags } \\
\text { of dependent variables and the second lag of all other independent variables. }\end{array}$} \\
\hline
\end{tabular}

These results (excluding labour demand shocks) are very interesting, see Table 9 below. The only variable in this estimation that is statistically significant is the lagged dependent variable and benefit duration (when time dummies are included). In other words, the model implodes: none of the other variables is significant. It is also worth noting that the sample size without this variable increases to 279 . Obviously, there were many missing values for this variable. Again the Hansen test for instrument validity suggests that the model is inappropriate as the number of instruments equals the number of observations. 
Table 9: Unemployment Regressions Arellano-Bond Estimation: Excluding labour demand shocks

\begin{tabular}{|c|c|c|}
\hline \multirow[t]{2}{*}{ Independent Variables } & \multicolumn{2}{|c|}{ Dependent variable: $\Delta \mathrm{u}_{\mathrm{it}}$} \\
\hline & 1 & 2 \\
\hline \multirow[t]{2}{*}{$\Delta \mathrm{u}_{\mathrm{it}-1}$} & $0.880 * * *$ & $0.900 * * *$ \\
\hline & $(0.0150)$ & $(0.0151)$ \\
\hline \multirow[t]{2}{*}{$\Delta \mathrm{EPL}$ temporary contracts $\mathrm{it}_{\mathrm{it}}$} & 0.188 & 0.203 \\
\hline & $(0.126)$ & $(0.206)$ \\
\hline \multirow[t]{2}{*}{$\Delta \mathrm{EPL}$ regular contracts ${ }_{\mathrm{it}}$} & 0.258 & 0.351 \\
\hline & $(0.502)$ & $(0.341)$ \\
\hline \multirow{2}{*}{$\Delta$ Benefit replacement ratio $_{\text {it }}$} & -0.0419 & 0.0744 \\
\hline & $(0.167)$ & $(0.136)$ \\
\hline \multirow[t]{2}{*}{$\Delta$ Benefit duration $_{\text {it }}$} & -0.0319 & $-0.247 * * *$ \\
\hline & $(0.0657)$ & $(0.0849)$ \\
\hline \multirow[t]{2}{*}{$\Delta$ Centralisation $_{\text {it }}$} & 0.334 & 0.237 \\
\hline & $(0.219)$ & $(0.165)$ \\
\hline \multirow[t]{2}{*}{$\Delta$ Co-ordination ${ }_{\text {it }}$} & -0.113 & -0.240 \\
\hline & $(0.298)$ & $(0.222)$ \\
\hline \multirow[t]{2}{*}{$\Delta$ Union density $_{\text {it }}$} & 0.181 & -0.238 \\
\hline & $(0.309)$ & $(0.288)$ \\
\hline \multirow[t]{2}{*}{$\Delta$ TFP shocks ${ }_{\text {it }}$} & 0.0136 & $-0.0218^{*}$ \\
\hline & $(0.0123)$ & $(0.0132)$ \\
\hline Time dummies & No & Yes \\
\hline Country dummies & Yes & Yes \\
\hline Observations & 279 & 279 \\
\hline Instruments & 267 & 267 \\
\hline AR1 test & 0.016 & 0.009 \\
\hline AR2 test & 0.070 & 0.303 \\
\hline Sargan Test & 0 & 0 \\
\hline Hansen Test & 1 & 1 \\
\hline \multicolumn{3}{|c|}{$\begin{array}{l}\text { Notes: } *, * * \text { and } * * * \text { denote statistical significance at the } 10 \%, 5 \% \text { and } 1 \% \text { levels respectively. } \\
\text { Robust standard errors are reported in parentheses. The models use DGMM and are representative } \\
\text { of the results from table } 2 \text { of Faccini's results. Both models use instruments comprising of all lags } \\
\text { of dependent variables and the second lag of all other independent variables. }\end{array}$} \\
\hline
\end{tabular}




\section{Conclusions}

In this paper we have provided a critical analysis of the econometric results in Faccini (2014) paper. The paper provides some "so-called" stylised facts that were selectively chosen and do not represent his chosen sample. We found major problems with his inadequate discussion of his estimation methods. The fixed effects estimation results are very sensitive to the sample selection and the crucial variable "employment protection_temporary contracts" loses statistical significance. The results using the Arellano-Bond estimation method using instrumental variables were generally unreliable as the number of instruments was too large as shown by the Sargan and Hansen tests. We find that when we provided tests of robustness and estimated the model using better econometric methods that his major conclusion that temporary contracts lead to increased unemployment is not justified. We showed that the choice of the sample was curious as he did not include the recent period of the global crisis, and excluded some countries from Europe without any justification. To conclude we find that there is no evidence to support the conclusion that greater use of temporary contracts would decrease unemployment. 


\section{References}

Faccini, R. (2014) Reassessing Labour Market Reforms: Temporary Contracts as a Screening Device, Economic Journal, 124, 167-200.

Nickell, S. J (1981) Biases in Dynamic Models with Fixed Effects, Econometrica, Econometric Society, 49 (6), 1417-26

Roodman, D. (2009) How to do xtabond2: An introduction to difference and system GMM in Stata, Stata Journal, 9 (1), 86-136. 